\title{
Carcass characteristics of Canindé goats subjected to feed restriction
}

\author{
Andreia Batista Bezerra ${ }^{1 *}$ Severino Gonzaga Neto ${ }^{1}$ Ariosvaldo Nunes de Medeiros ${ }^{1}$ Francisco

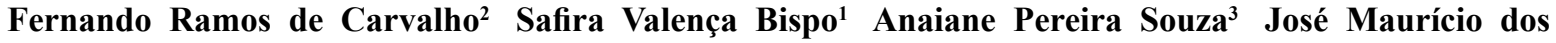 \\ Santos Neto ${ }^{4}$ Luana Paula dos Santos Ribeiro ${ }^{5}$
}

${ }^{1}$ Universidade Federal da Paraíba (UFPB), 58397 000, João Pessoa, PB, Brasil. E-mail: andreiabatist10@hotmail.com. *Corresponding author ${ }^{2}$ Universidade Federal Rural de Pernambuco (UFRPE), Recife, PE, Brasil.

${ }^{3}$ Universidade Estadual Paulista (UNESP), Jaboticabal, SP, Brasil.

${ }^{4}$ Universidade de São Paulo (USP), Piracicaba, SP, Brasil.

${ }^{5}$ Universidade Federal da Bahia (UFBA), Salvador, BA, Brasil.

\begin{abstract}
This study aimed to evaluate the effects of feed restriction on the carcass characteristics of castrated Caninde goat kids. A randomized block design was used, in which 21 goat kids with a body weight $(B W)$ of $15.9 \pm 1.0 \mathrm{~kg}$ were allocated to three levels of feed restriction: ad libitum, $20 \%$ and $40 \%$ restriction related to the ad libitum intake. The diet consisted of $55 \%$ forage (Tifton) and $45 \%$ concentrate. All animals were slaughtered when the kids fed ad libitum reached a BW of $25 \mathrm{~kg}$. After slaughter, the carcasses were chilled for 24 hours and subsequently measured. Kids fed ad libitum and subjected to $20 \%$ feed restriction showed similar morphometric carcass measurements, except for the chest circumference. Goat kids fed ad libitum exhibited greater values for warm and cold carcass yields compared with those subjected to $40 \%$ feed restriction and did not differ from the kids under $20 \%$ feed restriction. Weights of the commercial cuts showed decreasing mean values according to the intensity of feed restriction. Castrated Canindé goat kids subjected to 20\% feed restriction presented similar carcass yields and proportion of commercial cuts to those fed ad libitum.
\end{abstract}

Key words: carcass yield, commercial cuts, native breed.

Características de carcaça de caprinos Canindé submetidos à restrição alimentar

RESUMO: Objetivou-se com o presente estudo avaliar os efeitos da restrição alimentar sobre as características de carcaça de cabritos Canindé castrados. Foi utilizado um delineamento em blocos casualizados, no qual 21 cabritos com peso corporal (PC) de 15,9 $\pm 1,0 \mathrm{~kg}$ foram distribuídos por três níveis de restrição alimentar: ad libitum, 20\% e 40\% de restrição alimentar. A dieta consistiu de 55\% de volumoso (Tifton) e 45\% de concentrado. Os animais foram abatidos quando os cabritos alimentados ad libitum atingiram PC de 25kg. Após o abate, as carcaças foram resfriadas por 24 horas e, subsequentemente, mensuradas. Os cabritos alimentados ad libitum e submetidos à restrição alimentar de $20 \%$ apresentaram medidas morfométricas semelhantes, exceto para a circunferência do peito. Os cabritos alimentados ad libitum apresentaram maiores valores para rendimento de carcaça quente e fria em comparação àqueles submetidos à restrição alimentar de $40 \%$ e não diferiram entre os cabritos com restrição alimentar de $20 \%$. Os pesos dos cortes comerciais apresentaram médias decrescentes com a intensidade da restrição alimentar. Cabritos Canindé castrados submetidos à restrição alimentar de $20 \%$ obtém rendimento de carcaça e proporção dos cortes comerciais similares aos alimentados ad libitum.

Palavras-chave: cortes comerciais, raças nativas, rendimento de carcaça.

\section{INTRODUCTION}

Arid and semiarid regions cover an area of approximately 48 million $\mathrm{km}^{2}$ and are found in $2 / 3$ of the world's countries. Droughts are characteristic of the ecosystem of these regions and result in losses to the agricultural sector (OLIVEIRA et al., 2010). Raising of goats occurs in many semi-arid regions (ANDRADEMONTEMAYOR et al., 2011), since they show adaptability to regions with a low rainfall index and scarce forage availability. During the dry season, the goats consume low-quality feed as a consequence of low forage availability, thus resulting in a low productive performance. To make goat farming more profitable, especially during the long period of forage shortages, the feedlot farming system is presented as an alternative for improving production rates.

In feedlot systems, feed planning is essential to reduce costs. Use of feed restriction is an interesting alternative to reduce feed waste because it leads to greater profitability of the production system. Feed restriction is a strategy that has been investigated in some studies on meat goat production as well (PEREIRA FILHO et al., 2007; YÁÑEZ et al., 2007). 
However, studies on the farming of native goat breed in semi-arid regions, which present differentiated growth and physiological characteristics, are scarce.

In this context, this study aimed to evaluate the effects of feed restriction on the carcass characteristics of castrated Canindé goat kids.

\section{MATERIALS AND METHODS}

The experiment was conducted at the Experimental Station at Universidade Federal da Paraíba (UFPB), located in the municipality of São João do Cariri (Paraíba-Brazil). Humane animal care and handling procedures were followed according to the university's animal care committee.

We used 21 castrated Canindé kids, at approximately five months of age, with a body weight $(\mathrm{BW})$ of $15.9 \pm 1.0 \mathrm{~kg}$. Animals were weighted, identified, treated for ecto and endoparasites and vaccinated against clostridiosis, after which they were randomly distributed in stalls. Treatments consisted of three levels of intake: ad libitum; $20 \%$ of feed restriction; and $40 \%$ of feed restriction. These levels were based on the feed intake of the goat fed ad libitum, in each block of three goats where the daily intake of the restricted-fed goats within a block was determined by the dry matter intake (DMI) of the goat fed ad libitum within the same block on the previous day. Experimental diet was formulated as recommended by the NRC (2007) based on an average daily gain of $100 \mathrm{~g}$. A ratio of $55 \%$ roughage to $45 \%$ concentrate was used, and the ingredients were Tifton hay chopped in a forage chopper with a 10-mm mesh sieve, corn meal, soybean meal, limestone and a mineral supplement. Crude protein (CP) and metabolizable energy (ME) contents of diets were $164.7 \mathrm{~g} \mathrm{~kg}^{-1}$ and $2.5 \mathrm{Mcal} \mathrm{kg}$ ME. Feed was supplied twice a day as totally mixed ration and the quantity was adjusted to maintain the amount of orts at approximately $20 \%$ of the feed supplied to the animals subjected to the ad libitum level. Water was provided ad libitum for all animals.

Each group was slaughtered when the animal fed ad libitum reached BW of approximately $25 \mathrm{~kg}$. Kids were stunned via cerebral concussion with a captive bolt pistol, after which bleeding was performed for four minutes by severing the carotid and jugular veins. After skinning and gutting, the head (sectioned at the atlanto-occipital joint) and feet (sectioned at the carpal and tarsal-metatarsal joints) were removed to determine the carcass weight including the kidneys and perinephric-pelvic fat.

All non-carcass constituents were separated. The gastrointestinal tract (GIT), bladder
(B) and gallbladder (GB) were emptied, washed and weighted again to determine the empty BW (EBW), which was obtained based on the difference between the fasting weight at slaughter (FW) and weights of contents (GIT, B and GB).

Carcasses were kept in refrigeration for $24 \mathrm{~h}$ at $4^{\circ} \mathrm{C}$, where they were hung by the tarsal-metatarsal joints, and spaced $17 \mathrm{~cm}$ apart on average. At the end of this period, the carcass weight including the kidneys and perinephric-pelvic fat was recorded. The kidneys and the perinephric-pelvic fat were separated and weighted, and their values were subtracted from the carcasses to determine warm carcass weight (WCW), as well as cold carcass weight $(\mathrm{CCW})$. These weights were used to calculate the cold carcass yield (CCY) $(\%)=(\mathrm{CCW} / \mathrm{FW}) \times 100$ and warm carcass yield $(\mathrm{WCY})$ $(\%)=(\mathrm{WCW} / \mathrm{FW}) \times 100$. Then, the percent chilling loss (LC) was determined using the following equation: LC $=[(\mathrm{WCW}-\mathrm{CCW}) / \mathrm{WCW}] \times 100$. Biological yield was calculated based on the EBW as described by CEZAR \& SOUSA (2007).

Carcasses were subjectively evaluated using the visual method described by CEZAR \& SOUSA (2007) to estimate their degree of conformation, fat cover, and perinephric-pelvic fat score. In the evaluation of the carcass conformation, e proportion and distribution of muscle mass deposited on the skeleton were estimated assigning a value of 1 to the poorest conformation and 5 to an excellent conformation; for the fat cover, a value of 1 was assigned to the poorest cover and 5 to excellent cover.

The perinephric-pelvic fat score was determined by evaluating the amount of fat in the pelvic and abdominal cavities around the kidneys. The classification scale comprised three classes, according to the methodology of CEZAR \& SOUSA (2007): score 1 $=$ left kidney not fully covered with fat and pelvic cavity coated with a layer of fat; score $2=$ left kidney fully covered with fat and right kidney without any fat cover or partially covered and pelvic cavity with a median layer of fat; score $3=$ both kidneys fully covered with fat and pelvic cavity coated with a thick layer of fat.

In the carcasses, the following measurements were performed with a tape measure and a caliper (cm), according to the methodology described by YÁÑEZ et al. (2004): carcass external length; rump width; rump circumference; thigh circumference; chest circumference; chest width. Carcass was divided longitudinally into two halves: the right and left. In the left half, the following measurements were performed according to the methodology described by CEZAR \& SOUSA (2007): chest depth, leg length and carcass internal length. 
Leg compactness index (LCI) was calculated from the ratio between the carcass leg weight and length. Carcass compactness index (CCI) was calculated from the ratio between the $\mathrm{CCW}$ and the carcass internal length. After performing the morphometric measurements, carcass halves were sectioned into five anatomical regions (neck, ribs, loin, leg, shoulder). The loin eye area (LEA) was determined from a cross-section between the $12^{\text {th }}$ and the $13^{\text {th }}$ thoracic vertebrae of the left half of the cooled carcass. The LEA was recorded by placing a clear plastic sheet on the longissimus dorsi muscle and outlining the contour of the muscle, for subsequent determination of the area using AutoCAD ${ }^{\circledR}$.

The experimental design was a randomized block with three levels of intake and seven replicates, according to the following model:

$\mathrm{Y}_{\mathrm{ij}}=\mu+\mathrm{t}_{\mathrm{i}}+\beta_{\mathrm{j}}+\mathrm{e}_{\mathrm{ij}}$,

where:

$\mathrm{Y}_{\mathrm{ij}}=$ observed variable

$\mu=$ overall mean

$\mathrm{t}_{\mathrm{i}}=$ fixed effect of the feed restriction level

$\beta_{\mathrm{j}}=$ random effect block

$\mathrm{e}_{\mathrm{ij}}=$ random error associated with each observation

The data were analyzed using PROC

MIXED. An orthogonal partition of treatment effects into linear and quadratic degree effects was obtained following an analysis of variance $(\mathrm{P}<0.05)$. Means were compared by the Tukey-Kramer, using the probability level $(P<0.05)$ by the Statistical Analysis System software.

\section{RESULTS AND DISCUSSION}

Levels of feed restriction evaluated affected the carcass characteristics of Canindé goats because there was difference in DMI $(P<0.05)$, where the values were 737,557 and $444 \mathrm{~g} \mathrm{day}^{-1}$ for goat kids fed ad libitum, $20 \%$ and $40 \%$ feed restriction respectively.

The goat kids fed ad libitum responded similarly to those subjected to $20 \%$ feed restriction and better than the animals under $40 \%$ feed restriction for the following parameters: carcass internal length, chest depth, rump perimeter, thigh perimeter and leg length $(P<0.05)$. Animals with a greater slaughter weight tended to exhibit greater values for carcass measurements (Table 1). MARTINS et al. (2014) observed that in Boer, Canindé and Moxotó kids fed ad libitum, there was an increase of the carcass internal length, chest depth and rump circumference in comparison with kids subjected to $25 \%$ and $50 \%$ feed restriction. DHANDA et al. (2003) also reported an increase of carcass length according to the increase in the weight at slaughter in distinct breeds (Boer, Angorá, Feral and Saanen), slaughtered at intervals of $14-22 \mathrm{~kg}$ and $30-35 \mathrm{~kg}$.

There was a significant difference for chest perimeter, in which the animals fed ad libitum showed the greatest value (Table 1). According to YÁÑEZ et al. (2004), the chest circumference is a measurement influenced by the muscle and bone structure as well as by fat deposits. Thus, because the animals fed ad libitum ingested greater amounts of energy and protein than the groups subjected to $20 \%$ and $40 \%$ feed restriction; there were differences between the carcasses of these groups. An effect on the CCI $(\mathrm{P}<0.05)$ was observed, as the mean values decreased with increased feed restriction (Table 1). According to OSÓRIO \& OSÓRIO (2005), compactness is a measurement used to evaluate the amount of tissue deposited per unit of length and is therefore an indicator of carcass conformation. Thus, animals subjected to feed restriction deposited less tissue, with a consequent decrease in the amount of carcass meat produced. Despite the differences between the restriction levels, the values are within the usual range for goat carcasses.

The FW, EBW, WCW, CCW were influenced $(P<0.05)$ by the feed restriction levels (Table 2). Kids fed ad libitum exhibited the highest FW and; consequently, the highest carcass weights, which was associated with a greater average daily gain during the experiment $\left(101.1,73.3\right.$ and 48.4 g day $^{-1}$ for ad libitum, 20\% and $40 \%$ feed restriction respectively). According to ZAMIRI et al. (2012), the weight at slaughter is one of the factors that may influence the amount of meat, fat and bone in the carcass.

The kids fed ad libitum showed greater WCY and CCY values than the animals subjected to $40 \%$ restriction $(P<0.05)$. Biological yield was not affected by the feed restriction levels (Table 2), most likely because this parameter considers the EBW and, thus, eliminates the variations in GIT contents, which are material without any commercial value. These results are similar with the findings of MATTOS et al. (2006), who assessed the carcass yield in Canindé goats subjected to $0 \%$ and $30 \%$ feed restriction and did not report difference in biological yield, thus demonstrating that it was the GIT content that led to the differences in carcass yields.

There was an effect of the level of restriction on the carcass conformation, with lower values being observed for the animal carcasses subjected to feed restriction $(P<0.05)$. A lower conformation value indicated a lower proportion 
Table 1 - Morphometric measurements of the carcasses of Canindé goats subjected to levels of feed restriction.

\begin{tabular}{|c|c|c|c|c|c|c|}
\hline \multirow{2}{*}{ Variables } & \multicolumn{3}{|c|}{------------Feed restriction---------- } & \multirow{2}{*}{$\mathrm{SEM}^{1}$} & \multicolumn{2}{|c|}{------- $P$-value-------- } \\
\hline & $0 \%$ & $20 \%$ & $40 \%$ & & Lin & Quad \\
\hline Final body weight (kg) & $26.4 \mathrm{a}$ & $23.2 b$ & $21.0 \mathrm{c}$ & 0.381 & $<0.01$ & 0.29 \\
\hline Carcass external length $(\mathrm{cm})$ & 47.5 & 46.0 & 45.7 & 0.584 & 0.04 & 0.41 \\
\hline Carcass internal length $(\mathrm{cm})$ & $56.9 \mathrm{a}$ & $55.7 \mathrm{ab}$ & $53.3 \mathrm{~b}$ & 0.765 & $<0.01$ & 0.50 \\
\hline Rump perimeter $(\mathrm{cm})$ & $51.0 \mathrm{a}$ & $48.6 \mathrm{ab}$ & $46.6 b$ & 0.942 & $<0.01$ & 0.85 \\
\hline Thigh perimeter $(\mathrm{cm})$ & $35.0 \mathrm{a}$ & $34.3 \mathrm{ab}$ & $31.8 \mathrm{~b}$ & 0.757 & $<0.01$ & 0.37 \\
\hline Chest perimeter $(\mathrm{cm})$ & $64.6 \mathrm{a}$ & $61.3 b$ & $58.4 \mathrm{~b}$ & 0.789 & $<0.01$ & 0.79 \\
\hline Chest depth $(\mathrm{cm})$ & $26.9 \mathrm{a}$ & $25.7 \mathrm{ab}$ & $24.4 \mathrm{~b}$ & 0.356 & $<0.01$ & 0.87 \\
\hline Leg length (cm) & $38.1 \mathrm{a}$ & $37.5 \mathrm{ab}$ & $36.7 \mathrm{~b}$ & 0.429 & 0.03 & 0.84 \\
\hline Chest width (cm) & 17.9 & 16.6 & 15.8 & 0.613 & 0.028 & 0.67 \\
\hline Rump width (cm) & 18.3 & 18.00 & 17.21 & 0.371 & 0.056 & 0.59 \\
\hline $\operatorname{LCI}\left(\mathrm{kg} \mathrm{cm}^{-1}\right)$ & 0.48 & 0.48 & 0.47 & 0.0135 & 0.52 & 0.65 \\
\hline $\mathrm{CCI}\left(\mathrm{kg} \mathrm{cm}^{-1}\right)$ & $0.20 \mathrm{a}$ & $0.18 b$ & $0.16 \mathrm{c}$ & 0.0414 & $<0.01$ & 0.65 \\
\hline
\end{tabular}

$\mathrm{LCI}=$ leg compactness index; $\mathrm{CCI}=$ carcass compactness index

${ }^{\mathrm{a}-\mathrm{c}}$ For level of feed restriction within row, means without a common superscript letter differ by Tukey-Kramer test $(P<0.05)$.

${ }^{1}$ Standard error of mean (SEM).

of meat in the carcass because the conformation is directly related to the deposition of muscle mass on the skeleton. This result agreed with SILVA et al. (2012) that the carcass conformation is closely linked to the body condition.

The kids fed ad libitum presented similar mean values to the animals subjected to $20 \%$ feed restriction and greater values than those subjected to $40 \%$ feed restriction $(P<0.05)$ for perinephric-pelvic fat (Table 2). The greater deposition of internal fat and reduced deposition of external fat in the goats may be likely associated with the adaptation of these native animals to the dry climate of the semi-arid region of Brazil, leading to the emergence of adaptive traits over time.

The absolute weights $(\mathrm{kg})$ of the neck, ribs, shoulder, leg and loin decreased with increased feed restriction $(P<0.05)$, as shown in table 3 . The weight

Table 2 - Carcass characteristics of Canindé goats subjected to levels of feed restriction.

\begin{tabular}{|c|c|c|c|c|c|c|}
\hline \multirow{2}{*}{ Variables } & \multicolumn{3}{|c|}{--------------Feed restriction------------- } & \multirow{2}{*}{$\mathrm{SEM}^{1}$} & \multicolumn{2}{|c|}{-----------P-value-------- } \\
\hline & $0 \%$ & $20 \%$ & $40 \%$ & & Lin & Quad \\
\hline Fasting live weight (kg) & $24.2 \mathrm{a}$ & $21.4 b$ & $19.1 \mathrm{c}$ & 0.281 & $<0.01$ & 0.571 \\
\hline Empty body weight (kg) & $21.3 \mathrm{a}$ & $18.7 \mathrm{~b}$ & $16.2 \mathrm{c}$ & 0.294 & $<0.01$ & 0.950 \\
\hline Warm carcass weight $(\mathrm{kg})$ & $11.6 \mathrm{a}$ & $10.2 b$ & $8.84 \mathrm{c}$ & 0.206 & $<0.01$ & 0.851 \\
\hline Cold carcass weight (kg) & $11.3 \mathrm{a}$ & $9.90 \mathrm{~b}$ & $8.58 \mathrm{c}$ & 0.199 & $<0.01$ & 0.869 \\
\hline Chilling loss $(\%)$ & $2.35 b$ & $2.46 \mathrm{ab}$ & $2.76 \mathrm{a}$ & 0.106 & 0.013 & 0.47 \\
\hline Warm carcass yield $(\%)$ & $47.8 \mathrm{a}$ & $47.4 \mathrm{ab}$ & $45.5 b$ & 0.559 & $<0.01$ & 0.32 \\
\hline Cold carcass yield (\%) & $46.6 \mathrm{a}$ & $46.1 \mathrm{ab}$ & $44.4 \mathrm{~b}$ & 0.557 & $<0.01$ & 0.36 \\
\hline Biological yield (\%) & 54.5 & 54.3 & 54.6 & 0.638 & 0.91 & 0.78 \\
\hline Conformation (1-5 points) & $3.43 \mathrm{a}$ & $2.93 b$ & $2.71 b$ & 0.121 & $<0.01$ & 0.35 \\
\hline Fat cover (1-5 points) & 2.85 & 2.85 & 2.64 & 0.1429 & 0.30 & 0.55 \\
\hline Perinephric-pelvic fat (1-3 points) & $2.36 \mathrm{a}$ & $2.29 \mathrm{a}$ & $1.64 \mathrm{~b}$ & 0.1579 & $<0.01$ & 0.16 \\
\hline $\operatorname{LEA}\left(\mathrm{cm}^{2}\right)$ & 9.25 & 8.20 & 7.88 & 0.4170 & 0.033 & 0.49 \\
\hline
\end{tabular}

LEA $=$ loin eye area.

${ }^{\mathrm{a}-\mathrm{c}}$ For level of feed restriction within row, means without a common superscript letter differ by Tukey-Kramer test $(P<0.05)$

${ }^{1}$ Standard error of mean (SEM). 
Table 3 - Commercial cuts in the carcass of Canindé goats subjected to levels of feed restriction.

\begin{tabular}{|c|c|c|c|c|c|c|}
\hline \multirow{2}{*}{ Variables } & \multicolumn{3}{|c|}{ 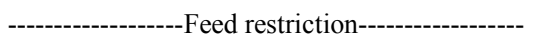 } & \multirow{2}{*}{$\mathrm{SEM}^{1}$} & \multicolumn{2}{|c|}{---------------------P -value----------------- } \\
\hline & $0 \%$ & $20 \%$ & $40 \%$ & & Lin & Quad \\
\hline Neck (kg) & $0.68 \mathrm{a}$ & $0.59 \mathrm{~b}$ & $0.50 \mathrm{c}$ & 0.0151 & $<0.01$ & 0.82 \\
\hline Shoulder (kg) & $0.97 \mathrm{a}$ & $0.87 \mathrm{~b}$ & $0.79 \mathrm{c}$ & 0.0170 & $<0.01$ & 0.79 \\
\hline Rib (kg) & $1.52 \mathrm{a}$ & $1.29 \mathrm{~b}$ & $1.13 \mathrm{c}$ & 0.0335 & $<0.01$ & 0.47 \\
\hline Leg (kg) & $1.69 \mathrm{a}$ & $1.50 \mathrm{~b}$ & $1.33 \mathrm{c}$ & 0.0350 & $<0.01$ & 0.84 \\
\hline Loin (kg) & $0.78 \mathrm{a}$ & $0.67 \mathrm{~b}$ & $0.57 \mathrm{c}$ & 0.0175 & $<0.01$ & 0.97 \\
\hline Neck (\%) & 12.0 & 12.0 & 11.5 & 0.234 & 0.16 & 0.45 \\
\hline Shoulder (\%) & $17.2 \mathrm{~b}$ & $17.7 \mathrm{ab}$ & $18.2 \mathrm{a}$ & 0.222 & $<0.01$ & 0.84 \\
\hline Rib (\%) & 26.9 & 26.2 & 26.2 & 0.265 & 0.065 & 0.29 \\
\hline Leg $(\%)$ & 29.9 & 30.4 & 30.8 & 0.356 & 0.11 & 0.99 \\
\hline Loin (\%) & 13.8 & 13.7 & 13.2 & 0.285 & 0.13 & 0.62 \\
\hline
\end{tabular}

${ }^{\mathrm{a}-\mathrm{c}}$ For level of feed restriction within row, means without a common superscript letter differ by Tukey-Kramer test $(P<0.05)$.

${ }^{1}$ Standard error of mean (SEM).

of the leg, loin, rib and neck followed the same increasing trend as the $\mathrm{CCW}$; however, the shoulder did not follow this trend $(P<0.05)$.

The group of animals fed ad libitum showed a lower mean shoulder yield compared with those subjected to $40 \%$ feed restriction $(P<0.05)$. The fact that only the shoulder exhibited differentiated growth is due to the greater amount of bones it contains; thus, the proportion will be greater in leaner carcasses. MARQUES et al. (2014) studied increasing levels of concentrate supplementation $\left(0,5,10\right.$ and $15 \mathrm{~g} \mathrm{~kg}^{-1}$ of $\left.\mathrm{BW}\right)$ in Moxotó goats (with similar BW to our study) grazing in the semiarid region and observed that the weights of the neck, rib, shoulder and leg cuts also increased. The proportion of the shoulder was the only cut influenced by the feed restriction levels, as observed in the present study.

\section{CONCLUSION}

Castrated Canindé goat kids subjected to $20 \%$ feed restriction exhibited similar carcass yields and proportions of commercial cuts to animals fed $a d$ libitum. Applying $20 \%$ feed restriction may represent an interesting alternative for native goat systems; however, future studies are needed mainly to focus on the cost-benefit analysis.

\section{ACKNOWLEDGMENTS}

The authors acknowledge Conselho Nacional de Desenvolvimento Científico e Tecnológico (CNPq) and Banco do Nordeste for the financial support.

\section{REFERENCES}

ANDRADE-MONTEMAYOR, H.M. et al. Alternative foods for small ruminants in semiarid zones, the case of Mesquite (Prosopis laevigata spp.) and Nopal (Opuntia spp.). Small Ruminant Research, v.98, p.83-92, 2011. Available from: <http://www.smallruminantresearch. com/article/S0921-4488(11)00098-8/abstrat>. Accessed: Jan. 22, 2016. doi: 10.1016/j.smallrumres.2011.03.023.

CEZAR, M.F.; SOUSA, W.H. Carcaças ovinas e caprinas: obtenção-avaliação-classificação. Uberaba: Agropecuária Tropical, 2007. 232p.

DHANDA, J.S. et al. Part 1. Growth, carcass and meat quality parameters of male goats: effects of genotype and live weight at slaughter. Small Ruminant Research, v.50, p.57-66, 2003. Available from: $<\mathrm{http} / /$ www.smallruminantresearch.com/article/S0921-4488(03)00112-3/ pdf>. Accessed: Oct. 01, 2015. doi: 10.1016/S0921-4488(03)00112-3.

MARQUES, C.A.T. et al. Performance and carcass traits of Moxotó growing goats supplemented on native pasture under semiarid conditions. Revista Brasileira de Zootecnia, v.43, p.151-159, 2014. Available from: $<$ http://www.scielo.br/scielo.php?pid=S1516$35982014000300008 \&$ script $=$ sci_arttext\&tlng $=\mathrm{pt}>$. Accessed: Dec. 01, 2015. doi: 10.1590/S1516-35982014000300008.

MARTINS, S.R. et al. Carcass and non-carcass component yields of crossbred Boer and Brazilian semiarid native goats subjected to different feeding levels. Tropical Animal Health and Production, v.46, p.647-653, 2014. Available from: <http://link.springer.com/ article/10.1007/s11250-014-0545-1>. Accessed: Apr. 24, 2015. doi: 10.1007/s11250-014-0545-1.

MATTOS, C.W. etal. Characteristics of carcass and non-carcass components of Moxotó and Canindé male kids under two feeding levels. Revista Brasileira de Zootecnia, v.35, p.2125-2134, 2006. Available from: <http:/ www.scielo.br/scielo.php?pid=S151635982006000700033\&script=sci arttext $>$.Accessed:Feb.01,2014.doi:10.1590/S1516-35982006000700033.

OLIVEIRA, F.T. et al. Palma forrageira: adaptação e importância para os ecossistemas áridos e semiáridos. Revista Verde de Agroecologia 
e Desenvolvimento Sustentável, v.5, p.27-37, 2010. Available from: <http://www.gvaa.com.br/revista/index.php/RVADS/article/ viewArticle/336>. Accessed: Nov. 12, 2015.

NATIONAL RESEARCH COUNCIL (NRC). Nutrient requirements of small ruminants: sheep, goats, cervids, and new world camelids. Washington, D.C.: National Academic, 2007. 292p.

OSÓRIO, J.C.S.; OSÓRIO, M.T.M. Produção de carne ovina: técnicas de avaliação in vivo e na carcaça. 2.ed. Pelotas: Universidade Federal de Pelotas, 2005. 82p

PEREIRA FILHO, J.M. et al. Efeito da restrição alimentar sobre algumas características de carcaça de cabritos f1 Boer x Saanen. Revista Ciência e Agrotecnologia, v.31, p.499-505, 2007. Available from: <http://www.scielo.br/pdf/\%0D/cagro/v31n2/a34v31n2.pdf> Accessed: Feb. 01, 2014. doi. 10.1590/S1413-70542007000200034

SILVA, N.V. et al. Efeito do feno de flor-de-seda sobre a carcaça e constituintes corporais de cordeiros Morada Nova. Archivos de Zootecnia, v.61, p.63-70, 2012. Available from: <http://scielo.isciii.
es/scielo.php?script=sci_arttext\&pid=S0004-05922012000100007 $>$. Accessed: Feb. 01, 2014. doi. 10.4321/S0004-05922012000100007.

YÁÑEZ, E.A. et al. Utilização de medidas biométricas para predizer características da carcaça de cabritos Saanen. Revista Brasileira de Zootecnia, v.33, p.1564-1572, 2004. Available from: $<$ http://www.sbz.org.br/revista/artigos/4065.pdf $>$. Accessed: Feb. 01, 2014. doi.: 10.1590/S1516-35982004000600024.

YÁÑEZ, E.A. et al. Effects of feed restriction on yield, retail cuts and tissue composition of carcass of Saanen kids. Revista Brasileira de Zootecnia, v.36, p.666-673, 2007. Available from: <http://www.scielo.br/scielo. php?pid=S151635982007000300021\&script=sci arttext\&tlng=es $>$. Accessed: Nov. 12, 2015. doi: 10.1590/S1516-35982007000300021.

ZAMIRI, M.J. et al. Effects of castration and fattening period on growth performance and carcass characteristics in Iranian goats. Small Ruminant Research, v.104, p.55-61, 2012. Available from: $\quad<$ http://www.smallruminantresearch.com/article/S09214488(11)00447-0/absttract>. Accessed: Nov. 12, 2015. doi: 10.1016/j.smallrumres.2011.11.008. 